\title{
Кількісний морфологічний аналіз особливостей ремоделювання артеріӥ дванадцятипалої кишки при резекціях різних об’емів паренхіми печінки
}

\begin{abstract}
Мета роботи: за допомогою кількісних морфологічних методів вивчити особливості ремоделювання артерій дванадцятипалої кишки при резекції різних об’ємів паренхіми печінки.

Матеріали і методи. Комплексом морфологічних методів досліджено дванадцятипалу кишку 43 статевозрілих білих щурівсамців, які були розділені на 4-и групи. 1-у групу складали 12 інтактних тварин, 2-у - 11 щурів, у яких було видалено 31,5 \% паренхіми печінки, 3-ю - 12 тварин, яким видаляли 42 \% паренхіми печінки, 4-у - 8 щурів після резекції 58,1 \% паренхіми печінки. Евтаназію дослідних тварин здійснювали кровопусканням в умовах тіопенталового наркозу через один місяць від початку експерименту. Із дванадцятипалої кишки виготовляли гістологічні мікропрепарати. Проводили морфометрію артерій дрібного калібру (26-50) мкм дванадцятипалої кишки, при якій вимірювали їх зовнішній, внутрішній діаметри, товщину медії та адвентиції, висоту ендотеліоцитів, діаметр їх ядер, визначали індекс Вогенворта, ядерно-цитоплазматичні відношення в ендотеліоцитах та відносний об’єм ушкоджених ендотеліоцитів. Кількісні показники обробляли статистично.

Результати досліджень та їх обговорення. Встановлено, що при резекції 31,5 \% паренхіми печінки досліджувані морфометричні показники змінювалися незначно. При видаленні 42 \% паренхіми печінки зовнішній діаметр вказаних судин статистично достовірно (р<0,001) збільшився на 8,1 \%, а товщина медії та адвентиції - відповідно, на 21,3 та 8,6 \%, індекс Вогенворта зріс у 1,76 раза, а внутрішній діаметр зменшився на 18,5 \%. Нерівномірно, диспропорційно при цьому змінювалися морфометричні параметри ендотеліоцитів та їх ядер, що призводило до виражених змін у них співвідношень між ядром та цитоплазмою, що свідчило про порушення клітинного структурного гомеостазу. Найбільш виражені зміни досліджуваних судин виявлено через місяць після видалення 58,1 \% паренхіми печінки. При цьому зовнішній діаметр артерій дрібного калібру статистично достовірно (р<0,001) зріс на 9,5 \%, товщина медії - на 36,9 \%, товщина адвентиції - на 44,8 \%, індекс Вогенворта - у 2,66 раза, вказуючи на істотне порушення пропускної здатності досліджуваних судин. Просвіт артерій дрібного калібру при цьому з вираженою статистичною достовірністю (р<0,001) зменшився на 31,4 \%.

Висота ендотеліоцитів даних судин виявилася зміненою на 13 \%, а їх ядер - на 8,4 \% (р<0,001). Ядерно-цитоплазматичні відношення в ендотеліоцитах досліджуваних артерій виявилися суттєво порушеними, а відносний об’єм ушкоджених ендотеліоцитів при цьому зріс у 15,9 раза. Наведене свідчить про виражене ремоделювання артерій дванадцятипалої кишки при видаленні 42 та 58,1 \% паренхіми печінки, яке призводить до погіршення кровопостачання органа, гіпоксії, дистрофії, некробіозу клітин і тканин, а пізніше до інфільтративних та склеротичних процесів.
\end{abstract}

Ключові слова: резекція печінки; дванадцятипала кишка; артерії; ремоделювання.

Постановка проблеми і аналіз останніх досліджень та публікацій. Резекцію печінки нерідко виконують у сучасних хірургічних клініках. Відомо, що видалення великих об'ємів печінки супроводжується виникненням пострезекційної портальної гіпертензії [2, 10], яка призводить до тяжких ускладнень: кровотечі з варикозно розширених вен стравоходу і шлунка, прямої кишки, асциту, спленомегалії, вторинного гіперспленізму, паренхіматозної жовтяниці, портосистемної енцефалопатії, печінкової недостатності $[2,10,12]$. Пострезекційна портальна гіпертензія призводить до структурної перебудови органів басейну ворітної печінкової вени, а також ремоделювання їх артеріального русла. Особливості структурної перебудови останнього у дванадцятипалій кишці при пострезекційній портальній гіпертензії вивчені недостатньо [4].

Мета роботи: за допомогою кількісних морфологічних методів вивчити особливості ремоделювання артерій дванадцятипалої кишки при резекції різних об’ємів паренхіми печінки.
Матеріали і методи. Комплексом морфологічних методів досліджена дванадцятипала кишка 43 статевозрілих білих щурів-самців, які були розділені на 4-и групи. 1-ша група нараховувала 12 iнтактних тварин, 2-га - 11 щурів, у яких було видалено 31,5 \% паренхіми печінки, 3-тя - 12 тварин, яким видаляли 42 \% паренхіми печінки, 4-та - 8 щурів після резекції 58,1 \% паренхіми печінки [4]. Щурі перебували в умовах віварію на звичайному раціоні. За тваринами проводили постійний нагляд. Їх регулярно зважували, спостерігали за активністю, апетитом, за шерстним покривом. Хворих щурів для експериментальних досліджень не використовували. Евтаназію дослідних тварин здійснювали кровопусканням в умовах тіопенталового наркозу через 1 місяць від початку експерименту. Усі маніпуляції та евтаназію щурів проводили з дотриманням основних принципів роботи 3 експериментальними тваринами відповідно до положення “Європейської конвенції про захист хребетних тварин, які використовуються для екс- 
периментальних та інших наукових цілей” (Страсбург, 1986 р.), “Загальних етичних принципів експериментів на тваринах”, ухвалених першим національним конгресом із біоетики (Київ, 2001 р.), а також Закону України “Про захист тварин від жорстокого поводження” (від 21.02.2006 р.) [ 5 ].

Вирізані шматочки із дванадцятипалої кишки фіксували в 10 \% нейтральному розчині формаліну і після відповідного проведення через етилові спирти зростаючої концентрації заливали у парафінові блоки за загальноприйнятою методикою. Гістологічні зрізи завтовшки 5-7 мкм після депарафінізації фарбували гематоксилін-еозином, за ван-Гізоном, Маллорі, Вейгертом, толуїдиновим синім [9]. Проводили морфометрію артерій дрібного калібру (26-50) мкм дванадцятипалої кишки, які знаходяться у більшому функціональному напруженні порівняно з артеріями більших розмірів $[3,11]$. При морфометрії артерій вимірювали їх зовнішній (ЗД) та внутрішній (ВД) діаметри, товщини медії (ТМ) та адвентиції (ТА), висоту ендотеліоцитів (ВЕ), діаметр їх ядер (ДЯЕ), визначали індекс Вогенворта (IB), ядерно-цитоплазматичні відношення в ендотеліоцитах (ЯЦВ) та відносний об'єм ушкоджених ендотеліоцитів (ВОУЕ) $[1,3,11]$. Морфометрію вказаних судин проводили за допомогою світлового мікроскопа "Olimpus BX-2” з цифровою відеокамерою та пакетом прикладних програм “Відео Тест 5,0” та “Відео розмір 5,0”. Кількісні величини обробляли статистично. Обробка результатів виконана у відділі системних статистичних досліджень Тернопільського державного медичного університету імені I. Я. Горбачевського в програмному пакеті Statsoft STATISTIKA. Різницю між порівнювальними величинами визначали за критеріями Манна-Уітні та Стьюдента [6].
Результати досліджень та їх обговорення. Отримані кількісні морфологічні показники артерій дрібного калібру ДПК подано в таблиці 1. Усестороннім аналізом представлених морфометричних параметрів виявлено, що вже при резекції 31,5 \% паренхіми печінки вони змінювалися. Так, при цьому зовнішній діаметр досліджуваних судин збільшився на 2,0 \%, товщина медії на 4,8 \%, товщина адвентиції - на 2,1 \%, порівняно з аналогічними контрольними показниками. Просвіт досліджуваних судин в умовах даного експерименту статистично достовірно $(\mathrm{p}<0,01)$ зменшився на 4,8 \%. Індекс Вогенворта, який відображає пропускну здатність артерій [11] з високою статистичною достовірністю ( $<0,001)$, зріс на $14,9 \%$, вказуючи на звуження просвіту даних артерій та зниження їх пропускної здатності.

У досліджуваних експериментальних умовах висота ендотеліоцитів артерій дрібного калібру ДПК зменшилася на 2,2 \%, їх ядер - на 1,3 \%, ядерно-цитоплазматичні відношення в ендотеліоцитах при цьому не змінилися, вказуючи на стабільність клітинного структурного гомеостазу [8]. Відносний об'єм ушкоджених ендотеліоцитів у вказаних судинах з високим ступенем достовірності ( $<<0,001)$ зріс майже у 2,1 раза.

При видаленні 42 \% паренхіми печінки досліджувані морфометричні параметри артерій ДПК змінювалися більшою мірою. Так, зовнішній діаметр вказаних судин статистично достовірно $(\mathrm{p}<0,001)$ збільшився на 8,1 \%, а товщини медії та адвентиціївідповідно, на 21,3 та 8,6 \%. Індекс Вогенворта цих судин при цьому з вираженою статистичною достовірністю $(p<0,001)$ зріс у 1,76 раза, а внутрішній діаметр зменшився на 18,5 \%. Нерівномірно, диспропорційно при цьому змінювалися морфометричні параметри ендотеліоцитів та їх ядер, що призводило

Таблиця 1. Морфометрична характеристика артерій дрібного калібру дванадцятипалої кишки

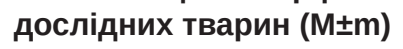

\begin{tabular}{||l|c|c|c|c||}
\hline \multirow{2}{*}{ Показник } & \multicolumn{3}{|c||}{ Група спостереження } \\
\cline { 2 - 5 } & 1 1-ша & 2-га & 3-тя & 4 -та \\
\hline ДЗ, мкм & $34,50 \pm 0,21$ & $35,20 \pm 0,24 *$ & $37,30 \pm 0,18^{* * *}$ & $37,80 \pm 0,21^{* * *}$ \\
\hline ДВ, мкм & $12,40 \pm 0,10$ & $11,80 \pm 0,09 * *$ & $10,10 \pm 0,09 * * *$ & $8,50 \pm 0,06^{* * *}$ \\
\hline ТМ, мкм & $10,30 \pm 0,06$ & $10,80 \pm 0,12^{*}$ & $12,50 \pm 0,07 * * *$ & $14,10 \pm 0,12^{* * *}$ \\
\hline ТА, мКм & $5,80 \pm 0,02$ & $5,92 \pm 0,03^{*}$ & $6,30 \pm 0,03^{* * *}$ & $8,40 \pm 0,06^{* * *}$ \\
\hline ІВ, \% & $774,1 \pm 6,0$ & $889,80 \pm 7,2^{* * *}$ & $1362,6 \pm 10,5^{* * *}$ & $2062,2 \pm 15,3^{* * *}$ \\
\hline ВЕ, мкм & $5,98 \pm 0,02$ & $5,85 \pm 0,03^{*}$ & $5,45 \pm 0,03^{* * *}$ & $5,20 \pm 0,02^{* * *}$ \\
\hline ДЯЕ, мкм & $3,08 \pm 0,02$ & $3,04 \pm 0,003$ & $2,90 \pm 0,02^{* *}$ & $2,82 \pm 0,01^{* * *}$ \\
\hline ЯЦВ & $0,265 \pm 0,002$ & $0,270 \pm 0,003$ & $0,283 \pm 0,002^{* *}$ & $0,290 \pm 0,002^{* * *}$ \\
\hline ВОУЕ, \% & $2,30 \pm 0,02$ & $4,80 \pm 0,05^{* * *}$ & $19,40 \pm 0,12^{* * *}$ & $36,50 \pm 0,24^{* * *}$ \\
\hline \hline
\end{tabular}

Примітки: * - p<0,05; ** - p<0,01; *** - p<0,001, порівняно з 1-ю групою спостережень. 
до виражених змін у них співвідношень між ядром та цитоплазмою, що свідчило про порушення клітинного структурного гомеостазу [8].

Найбільш виражені зміни досліджуваних судин ДПК виявлено через місяць після видалення 58,1 \% паренхіми печінки. При цьому зовнішній діаметр артерій дрібного калібру статистично достовірно $(\mathrm{p}<0,001)$ зріс на 9,5 \%, товщина медії - на 36,9 \%, товщина адвентиції - на 44,8 \%. Індекс Вогенворта у даних умовах експерименту 3 високим ступенем статистичної достовірності $(\mathrm{p}<0,001)$ збільшився у 2,66 раза, вказуючи на істотне порушення пропускної здатності досліджуваних судин [11]. Просвіт артерій дрібного калібру ДПК через місяць після видалення 58,1 \% паренхіми печінки з вираженою статистичною достовірністю ( $<<0,001)$ зменшився на 31,4 \%. Виражене зростання індексу Вогенворта та суттєве звуження досліджуваних артерій вказували на істотне погіршення кровопостачання стінки ДПК.

Висота ендотеліоцитів даних судин виявилася зміненою на 13,0 \%, а їх ядер - на 8,4% (p<0,001). Ядерно-цитоплазматичні відношення в ендотеліоцитах досліджуваних артерій неушкодженої ДПК дорівнювали $(0,265 \pm 0,002)$, а через місяць після резекції 58,1 \% паренхіми печінки (0,296士0,002). Наведені морфометричні параметри статистично достовірно ( $<20,001)$ різнилися між собою і останній показник перевищував попередній на 11,7 \%. Відносний об’єм ушкоджених ендотеліоцитів при цьому зріс у 15,9 раза $(\mathrm{p}<0,001)$, порівняно з аналогічним контрольним показником.

Гістологічно в оболонках стінки ДПК спостерігалися виражені судинні розлади, набряки строми, осередки дистрофічно, некробіотично, апоптично змінених епітеліоцитів, вогнищеві інфільтрати та розростання сполучної тканини. Спостерігався також набряк ендотеліоцитів, їх дистрофія, некробіо3, десквамація та проліферація. Останнє свідчило про наявність гіпоксії. Виявилося також просякання мембран, ендотеліоцитів, судинної стінки білками плазми. У деяких досліджуваних судинах спостерігалися осередки фібриноїдного набряку та некрозу, що свідчило про їх виражене пошкодження.

Відомо, що ендотеліоцити судин синтезують різні біологічно активні речовини, необхідні для регуляції життєво важливих процесів організму і зсідання крові, регуляція тонусу судин, скоротливість серця, дифузія води, іонів, продуктів метаболізму. Ендотеліоцити здійснюють бар’єрну, продукційну, гемостатичну, метаболічну, транспортну, репаративну функцію, синтезують оксид азоту (NO). Пошкодження ендотеліоцитів призводить до їхньої дисфункції, блокади NO-синтази, зменшення синтезу NO, активації процесів його деградації, що супроводжується спазмом та звуженням судин [7]. Останнє погіршує кровопостачання органів, призводить, підтримує та посилює гіпоксію, яка ускладнюється набряком, дистрофією, некробіозом тканин і клітин.

На основі отриманих результатів проведеного дослідження та даних літератури можна стверджувати, що видалення великих об’ємів паренхіми печінки призводить не тільки до портальної гіпертензії, але й вираженої структурної перебудови (ремоделювання) артерій дванадцятипалої кишки, що характеризується потовщенням їх стінки, звуженням просвіту, ушкодженням ендотеліоцитів, погіршенням кровопостачання органа.

Висновок. Видалення 42 \% і більше паренхіми печінки призводить до вираженого ремоделювання артерій дванадцятипалої кишки, яке характеризується потовщенням їхньої стінки, звуженням просвіту, ураженням ендотеліоцитів, ендотеліальною дисфункцією, погіршенням кровопостачання органа, гіпоксією, дистрофією, некрозом тканин і клітин, вогнищевими клітинними інфільтратами, склерозуванням. Вираженість структурної перебудови артерій дванадцятипалої кишки залежить від видаленого об’єму паренхіми печінки. Особливості ремоделювання артерій дванадцятипалої кишки при резекціях печінки варто враховувати в практичній медицині при профілактиці та корекції пострезекційних ускладнень.

Перспективи подалыших досліджень. Всебічне адекватне вивчення закономірностей ремоделювання артерій дванадцятипалої кишки в умовах пострезекційної портальної гіпертензії дозволить суттєво розширити її діагностику, корекцію та профілактику.

\section{СПИСОК ЛІТЕРАТУРИ}

1. Автандилов Г. Г. Основы количественной патологической анатомии / Г. Г. Автандилов. - М. : Медицина, 2002. 240 c.

2. Вишневський В. А. Сегментарные резекции, отдаленные результаты при злокачественных опухолях печени / В. А. Вишневский, М. Г. Ефанов, И. В. Казаков // Укр. журнал хірур-

гіï. - 2012. - № 1 (16). - С. 5-15.

3. Гнатюк М. С. Морфометрична оцінка вікових особливостей ремоделювання артерій дванадцятипалої кишки / М. С. Гнатюк, Л. В. Татарчук, М. В. Данів // Клінічна анатомія та оперативна хірургія. - 2009. - Т. 8, № 4. - С. 54-57.

4. Гнатюк М. С. Морфометрична оцінка особливостей ремо- 
делювання структур дванадцятипалої кишки при резекції різних об’ємів печінки / М. С. Гнатюк, Л. В. Татарчук, О. Б. Ясіновський // Науковий вісник Ужгородського університету. Серія “Медицина”. - 2016. - Вип. 1 (53). - С. 92-95.

5. Загальні етичні принципи експериментів на тваринах // Ендокринологія. - 2003. - Т. 8, № 1. - С. 142-145.

6. Лапач С. Н. Статистические методы в медико-биологических исследованиях Excell / С. Н. Лапач, А. В. Губенко, П. Н. Бабич. - К. : Морион, 2001. - 410 с.

7. Макаров М. А. Роль дисфункции эндотелия и регидности артерий в патогенезе хронической обструктивной болезни легких / М. А. Макаров, С. Н. Авдеев, А. Г. Чучалин // Терапевтический архив. - 2012. - № 3. - С. 74-80.

8. Саркисов Д. С. Структурне основы адаптации и компенсации нарушенных функций / Д. С. Саркисов. - М. : Медицина, 1998. - 230 с.

\section{REFERENCES}

1. Avtadnilov, G.G. (2002). Osnovy kolichestvennoy patologicheskoy anatomii [Basis of quantitative pathological anatomy]. Moscow: Meditsina [in Russian].

2. Vishnevskiy, V.A., Yefanov, M.G., \& Kazakov, I.V. (2012). Segmentarnyye rezektsyi, otdaliennyye rezultaty pri zlokachestvennykh opukholyakh pyechieni [Segmentar resections, long-term results in malignant liver tumors]. Ukr. Zhurnal Khirurgii - Ukrainian Journal of Surgery, 1 (16), 5-15 [in Ukrainian].

3. Hnatiuk, M.S., Tatarchuk, L.V., \& Daniv, M.V. (2009). Morfometrychna otsinka vikovykh osoblyvostei remodeliuvannia arterii dvanadtsiatypaloi kyshky [Morphometric evaluation of the features of remodeling arteries of duodenum]. Klinichna anatomiia ta operatyvna khirurhiia - Clinical Anatomy and Operative Surgery, 8, (4) 54-57 [in Ukrainian].

4. Hnatiuk, M.S., Tatarchuk, L.V., \& Yasinovskyi, O.B. (2016). Morfometrychna otsinka osoblyvostei remodeliuvania struktur dvanadtsiatypaloi kyshky pry resektsii riznykh obiemiv pechinky [Morphometric evaluation of the features of remodeling of duodenal structures during resection of different volumes of the liver]. Naukovyi visnyk Uzhhorodskoho universytetu. Seriia "Medytsyna" - Scientific Journal of Uzhhorod University. Series "Medicine", 1 (49), 3-5 [in Ukrainian].

5. (2003). Zahalni etychni pryntsypy eksperymentiv na tvarynakh [General ethical principles of experiments on animals]. Endokrynolohiia - Endocrinology, 8, 1, 142-145 [in Ukrainian]. 6. Lapach, S.N., Gubenko, A.V., \& Babich, P.N. (2001). Statistichieskiye metody vmediko-biologicheskikh issledovaniyakh Excell [Statistical methods in medicobiological investigations
9. Сорочинников А. Г. Гистологическая и микроскопическая техника / А. Г. Сорочинников, А. Е. Доросевич. - М. : Медицина. - 2007. - 448 с.

10. Федоров В. Д. Основные осложнения обширных резекций печени и пути их предупреждения / В. Д. Федоров, В. А. Вишневский, Н. А. Назаренко [и др.] // Бюлл. сибирской медицины. - 2007. - № 4. - С. 16-24.

11. Шорманов С. В. Гистологические и ультраструктурные изменения печени при экспериментальном стенозе легочного ствола на стадии декомпенсации / С. В. Шорманов, С. В. Куликов // Морфология. - 2010. - № 3. - С. 46-50.

12. Nanashima A. A modified grading system for posthepatectomy metastatic liver cancer originating form colorectal carcinoma / A. Nanashima, Y. Sumida, T. Abo // J. Surg. Oncol. - 2008. - No. 98. - P. 363-370.

Excell]. Kyiv: Morion [in Russian].

7. Makarov, M.A., Avdyeyev, S.G., Chuchalin, A.G. (2012). Rol disfunktsyi endoteliya i regidnosti arteriy $\mathrm{v}$ patogeneze khronicheskoy obstruktivnoy boliezni liegkikh [Role of disfunction of endothelial cell in medical and biological investigation]. Terapevtichiskiy arkhiv - Theraputical Archive, 3, 74-80 [in Russian].

8. Sarkisov, D.S. (1998). Strukturnyye osnovy adaptatsyi $i$ kompensatsyi narushennykh funktsyy [Structural basis adaptation and compensation damage function]. Moscow: Meditsina [in Russian].

9. Sorochinnikov, A.G., \& Dorosyevich, A.Ye. (2007). Gistologichieskaya i mikroskopicheskaya tekhnika [Histological and microscopic equipments]. Moscow: Meditsina [in Russian]. 10. Fodorov, V.D., Vishnyevskiy, V.A. \& Nazarenko, N.A. (2007). Osnovnye oslozhnieniya obshyrnykh rezektsyy pecheni i puti ikh preduprezhdeniya [The main complications of extensive liver resections and ways to prevent them]. Byull. Sibirskoy mieditsyny - Journal of Siberian Medicine, 4, 16-24 [in Russian]. 11. Shormanov, S.V., \& Kulikov, S.V. (2010). Gistologichieskiye i ultrastrukturnye izmineniya pecheni pri ekspierimentalnom stenoze legochnogo stvola na stadii dekompensatsyi [Histological and ultrastructural changers at experimental stenosis of pulmonary trunk at insufficiency]. Morfologiya - Morphology, 3, 46-50 [in Russian].

12. Nanashima, A., Sumida, Y., \& Abo, T.(2008). A modified grading system for post-hepatectomy metastatic liver cancer originating form colorectal carcinoma. J. Surg. Oncol., 98, 363370 . 


\title{
QUANTITATIVE MORPHOLOGICAL ANALYSIS OF FEATURES OF ARTERIES REMODELING OF DUODENUM AT DIFFERENT VOLUME RESECTIONS OF LIVER PARENCHYMA
}

\begin{abstract}
The aim of the work: quantitative morphological methods to study the features of remodeling of the arteries of the duodenum at resection of different volumes of liver parenchyma.

Materials and Methods. The complex of morphological methods examined the duodenum of 43 sexually mature white male rats, which were divided into 4 groups. The first group consisted of 12 intact animals, second - 11 rats, in which $31.5 \%$ of liver parenchyma was removed, third -12 animals, which removed $42 \%$ of liver parenchyma, 4-8 rats after resection 58, 1 \% liver parenchyma. Euthanasia of experimental animals was carried out by bloodletting in conditions of thiopental anesthesia 1 month after the beginning of the experiment. From the duodenum histological preparations were made. The morphometry of arteries of small caliber (26-50) microns of duodenum was measured, in which their external and internal diameters, the thickness of the media and adventitia, the height of the endothelial cells, the diameter of their nuclei were determined, the Wogenworth index, the nuclear-cytoplasmic ratios in the endothelial cells and the relative volume damaged endothelial cells. Quantitative indicators were processed statistically.

Results and Discussion. It was established that during resection of $31.5 \%$ of liver parenchyma morphometric indices studied were insignificantly changed. When removing $42 \%$ of liver parenchyma, the outer diameter of these vessels increased statistically significantly ( $p$ $<0.001$ ) by $8.1 \%$, while the thickness of the media and adventia was $21.3 \%$ and $8.6 \%$, respectively, and the index Wogenworth increased 1.76 times, and the internal diameter decreased by $18.5 \%$. The morphometric parameters of endothelial cells and their nuclei, which resulted in marked changes in their correlation between the nucleus and the cytoplasm, evidenced the disruption of cellular structural homeostasis, were unevenly and disproportionally altered. The most pronounced changes in the examined vessels were detected one month after the removal of $58.1 \%$ of liver parenchyma. At the same time, the outer diameter of small-caliber arteries has increased statistically significantly ( $<0.001$ ) by $9.5 \%$, the thickness of the media is by $36.9 \%$, the thickness of the adventitia is by $44.8 \%$, the Wogenworth index is 2.66 times, indicating significant violation of the capacity of the examined vessels. The internal diameter of small-caliber arteries with a significant statistical significance $(\mathrm{p}<0.001)$ decreased by $31.4 \%$. The height of the endothelial cells of the vessels was changed by $13.0 \%$, and their nuclei - by $8.4 \%(\mathrm{p}<0.001)$. The nuclear-cytoplasmic relationships in the endothelial cells of the studied arteries were significantly disturbed, and the relative volume of damaged endothelial cells increased by 15.9 times. The presented evidence shows a pronounced remodeling of arteries of the duodenum in the removal of 42 and $58.1 \%$ of liver parenchyma, which leads to deterioration of blood supply to the organ, hypoxia, dystrophy, necrobiosis of cells and tissues, and later infiltrative and sclerotic processes.
\end{abstract}

Key words: resection of the liver; duodenum; arteries; remodeling.

\section{л. В. ТАТАРЧУК}

ГВУз “Тернопольский государственный медицинский университет имени И. Я. Горбачевского МЗ Украины”

\section{КОЛИЧЕСТВЕННЫЙ МОРФОЛОГИЧЕСКИЙ АНАЛИЗ ОСОБЕННОСТЕЙ РЕМОДЕЛИРОВАНИЯ АРТЕРИЙ ДВЕНАДЦАТИПЕРСТНОЙ КИНКИ ПРИ РЕЗЕКЦИЯХ РАЗНЫХ ОБЫЕМОВ ПАРЕНХИМЫ ПЕЧЕНИ}

\begin{abstract}
Цель работы: количественными морфологическими методами изучить особенности ремоделирования артерий двенадцатиперстной кишки при резекции разных объемов паренхимы печени.

Материалы и методы. Комплексом морфологических методов исследована двенадцатиперстная кишка 43 половозрелых белых крыс-самцов, которые были разделены на 4 группы. 1-я группа насчитывала 12 интактных животных, 2-я - 11 крыс, у которых было удалено 31,5 \% паренхимы печени, 3-я - 12 животных, которым удаляли 42 \% паренхимы печени, 4-я - 8 крыс после резекции 58,1 \% паренхимы печени. Эвтаназия животных осуществлялась кровопусканием в условиях тиопенталового наркоза через 1 месяц от начала эксперимента. Из двенадцатиперстной кишки изготовляли гистологические микропрепараты. Проводили морфометрию артерий мелкого калибра (26-50) мкм двенадцатиперстной кишки, при которой измеряли их внешний и внутренний диаметры, толщину медии, адвентиции, высоту эндотелиоцитов, диаметр их ядер, определяли индекс Вогенворта, ядерно-цитоплазматические отношения в эндотелиоцитах и относительный объем поврежденных эндотелиоцитов. Количественные показатели обрабатывали статистически.

Результаты исследований и их обсуждение. Выявлено, что при резекции 31,5 \% паренхимы печени исследуемые морфометрические показатели изменялись незначительно. При удалении 42 \% паренхимы печени внешний диаметр этих сосудов статистически достоверно ( $<0,001)$ увеличился на $8,1 \%$, а толщина медии и адвентиции - соотвественно - на 21,3 та 8,6 \%, индекс Вогенворта - у 1,76 раза, а внутренний диаметр уменшился на 18,5%. Неравномерно, диспропорционально при этом изменялись морфометрические параметры эндотелиоцитов и их ядер, что приводило к выраженным изменениям соотношений между ядром и цитоплазмой и свидетельствовало о нарушениях клеточного структурного гомеостаза. Наиболее выраженные изменения исследуемых сосудов выявлены через месяц после резекции 58,1 \% паренхимы печени. При этом внешний диаметр артерий мелкого калибра статистически достоверно ( $<0,001)$ увеличился на 9,5 \%, толщина медии - на 36,9 \%, адвентиции - на 44,8 \%, индекс Вогенворта - в 2,66 раза, указывая на существенное нарушение пропускной способности исследуемых сосудов. Просвет артерий мелкого калибра при этом с выраженной статистической достоверностью $(\mathrm{p}<0,001)$ уменьшился на 31,4 \%. Высота эндотелиоцитов этих сосудов выявилась измененной на 13,0 \%, а их ядер - на 8,4 \% (р<0,001). Ядерноцитоплазматические отношения в эндотелиоцитах исследуемых артерий были существенно нарушенными, а относительный объем поврежденных эндотелиоцитов при этом увеличился в 15,9 раза. Это свидетельствует о выраженном ремоделировании артерий двенадцатиперстной кишки при резекции 42 та 58,1 \% паренхимы печени, которое приводит к ухудшению кровоснабжения органа, гипоксии, дистрофии, некробиоза клеток и тканей, а позднее к инфильтративным и склеротическим процессам.
\end{abstract}

Ключевые слова: резекция печени; двенадцатиперстная кишка; артерии; ремоделирование. 